\title{
Effect of potassium and sulphur on yield and yield attributes of onion and chilli intercrops in a vertisol
}

\section{K.S. POORNIMA, N. MAMATHA AND H. S. RAMESH}

\section{MEMBERS OF RESEARCH FORUM:}

Corresponding author : K.S. POORNIMA, Fertilizer Control Laboratory, MANDYA (KARNATAKA) INDIA

Email: poornapavana@gmail.com

Co-authors :

N. MAMATHA, Office of Assistant Registrar of Cooperative Societies, Sahakara Bhavan, SHIMOGA (KARNATAKA) INDIA

Email : mamathadavanagere@gmail.com

H.S. RAMESH, Department of Veterinary Physiology and Biochemistry, Veterinary College,

Vinobhanagar, SHIMOGA (KARNATAKA) INDIA

Email: ramamabhi@gmail.com

Received : 15.12.2015; Revised : 21.03.2016; Accepted : 17.04 .2016

\section{Summary}

A field experiment was conducted during Kharif 2006 on a vertisol to study the effect of potassium and sulphur on yield and yield parameters of onion and chilli intercrops grown with four levels of potassium $\left(0,50,75\right.$ and $\left.100 \mathrm{~kg} \mathrm{~K}_{2} \mathrm{O} \mathrm{ha}^{-1}\right)$ and three levels of sulphur $(0,15$ and $30 \mathrm{~kg} \mathrm{~S} \mathrm{ha}^{-1}$ ). Yield and yield attributes of onion and chilli increased with the individual application of $100 \mathrm{~kg} \mathrm{~K}_{2} \mathrm{O} \mathrm{ha}^{-1}$ and $30 \mathrm{~kg} \mathrm{Sha}^{1}$. The combined application of $100 \mathrm{~K}_{2} \mathrm{O}$ and 30 $\mathrm{kg} \mathrm{S} \mathrm{ha}^{-1}$ recorded the maximum yield of both onion $\left(19.52 \mathrm{tha}^{-1}\right)$ and chilli $\left(3.90 \mathrm{q} \mathrm{ha}^{-1}\right)$ and also onion equivalent yield (23.42 $\left.\mathrm{tha}^{-1}\right)$ of the intercropping system.

Key words : Yield, Soil sodium, Soil potassium, Bulb, Vertisol, Intercrops

How to cite this article : Poornima, K.S., Mamatha, N. and Ramesh, H.S. (2016).Effect of potassium and sulphur on yield and yield attributes of onion and chilli intercrops in a vertisol. Asian J. Soil Sci., 11 (1) : 58-61 : DOI : 10.15740/HAS/AJSS/11.1/58-61. 